\title{
The effect of export incentives on export promotion: the case of Korea
}

\author{
Jai S. Mah*
}

\begin{abstract}
This paper examines whether or not one of the export incentives, i.e. export insurance, provided by the Korean government has promoted the export supply of Korea. The role of transaction cost in administering the export insurance system is considered in the current analysis. The small sample cointegration tests show that the concerned variables are not cointegrated. The empirical evidence using the first differenced data shows that the provision of export incentives in terms of export insurance by the government does not have a significant effect on increasing the export supply of Korea.
\end{abstract}

JEL classification number: F13

Keywords: Export incentives, Korea, export promotion.

Submission Date: 22/02/2010 Revision Date: 06/04/2010

Acceptance Date: 15/04/2010

* Professor, Division of International Studies, Ewha Womans University, Seodaemun-gu, Seoul 120-750, South Korea. Tel.: +82-2-3277-4683, Fax: +82-2-445-8836, E-mail: jsmah59@yahoo.com 


\section{Introduction}

The global trading system governed by the World Trade Organization (WTO) has prohibited the governmental provision of subsidies to promote exports. Export subsidy is defined under the WTO as the grant of tax or financial benefit provided by the government to private companies contingent upon export performance. Although export subsidies thus defined have been prohibited, a few types of incentives provided to exporters are allowed even under the current WTO system, which include export insurance and duty drawback. In developed countries and upper middle income developing countries where the average import tariff rate is fairly low, the export insurance system can be regarded as a meaningful export incentive. If export insurances has been effective in promoting exports, WTO Members may promote their exports by establishing or strengthening their export insurance systems (Abraham, Couwenberg and Dewit (1992); Mah and Milner (2005). Therefore, it is necessary to examine whether or not provision of export insurance contributes to export promotion.

As a country which has pursued the export-led economic growth strategy, Korea has maintained the export insurance system since 1969. Although provisions of export incentives such as export insurance may be beneficial to export promotion, administrative costs would be needed in maintaining such export promoting institutions. The existence of such administrative costs may influence the incentive nature of export insurance. Therefore, in addition to testing the effectiveness of export insurance systems on export promotion, the current study examines whether or not ignorance of transaction costs may result in incorrect conclusions regarding the effectiveness of export insurance systems on the export supplies of Korea. The structure of this paper is as follows. Section II explains the incentives that can be provided to exporters in the current WTO system. Section III introduces the institutional aspects of the export insurance system of Korea. Section IV explains the models and statistical data. Empirical results appear in Section V. Conclusions are provided in Section VI.

\section{Export Incentives in the WTO System}

The Agreement on Subsidies and Countervailing Measures as a result of the settlement of the Uruguay Round in 1994, i.e. the UR Subsidies Code, stipulates that a subsidy exists if a financial or tax benefit is conferred by a government or any public body (Article 1 of the UR Subsidies Code). There are three types of subsidies in the Subsidies Code: actionable subsidies that may be subject to the imposition of countervailing duties (CVDs) by the government of importing countries; non-actionable subsidies that are free from the CVDs; and prohibited subsidies which are not allowed. Most Members of the WTO provide 
certain types of subsidies for various purposes including indirect promotion of strategic industries. The subsidies prohibited in the WTO system include: export subsidies and import-substituting subsidies (Article 3 of the UR Subsidies Code).

A Member of the WTO is neither allowed to grant nor maintain such prohibited subsidies, including export subsidies and import-substituting subsidies. The UR Subsidies Code illustrates the list of export subsidies, which includes the provision of duty drawback in excess of those levied on imported inputs that are used in the production of the exported product is regarded as one of the examples of export subsidies. Another example of export subsidy illustrated in the UR Subsidies Code relates to export insurance. That is, the provisions by governments or special institutions controlled by governments of export insurance programs, of insurance against increases in the cost of exported products at premium rates which are inadequate to cover the long-term operating costs and losses of the programs, are regarded as another type of export subsidy (Annex I.(i) and (j) of the UR Subsidies Code).

According to the UR Subsidies Code explained above, provisions of duty drawback and/or export insurance to exporters not exceeding a certain threshold level would not be regarded as export subsidies which are prohibited in the WTO system. That is, duty drawback and export insurance not exceeding the threshold level can be regarded as export incentives, benefiting exporters, but not as prohibited subsidies. Of those two types of export incentives, provision of duty drawback can be regarded as a meaningful export incentive in countries whose average import tariff rates are not low. Since the import tariff rates in general reflect the economic development level of the concerned countries, developing countries tend to show high average import tariff rates. The studies on the duty drawback system as an export incentive allowed in the current WTO system include the works of Chao, et. al. (2001) and Mah (2007) applied to China, which shows fairly high average import tariff rates. Since the average import tariff rates of developed countries and upper middle income developing countries are as low as a few to several percent, duty drawback may not be a meaningful export incentive in such countries. It means that the provision of export insurance can be considered as the most important export incentive that those governments can use in the WTO system.

\section{The Export Insurance System of Korea}

The Korean economy has been characterized as the export-led economic growth. The Korean government enacted the Export Insurance Law to promote exports and, as an export credit agency, the Korea Re-insurance Company which was a state-owned enterprise was put in charge of export insurance services in 1969. The Law originally mimicked the Japanese Export Credit Insurance Law in the sense that Japan had been the heaviest user of 
the export insurance system. To support the export insurance businesses, the Export Insurance Fund was established by the government. The amount of the Fund started from a mere 0.3 billion won in 1969, but continued to increase to 25 billion won in 1988 and then to 2 trillion won at the end of 2007. The Export Import Bank was established in 1976 and was put in charge of the export insurance services. Realizing the necessity for an institution fully devoted to export insurance services, the government established the Korea Export Insurance Corporation (KEIC) in 1992 and it has been in charge of the export insurance system of Korea since then (KEIC (2003).

The values of export insurance underwriting have increased from a mere 1.2 billion won in 1969 to 1.5 trillion won in 1991 and then to 82.7 trillion won in 2006 . The coverage ratio, defined as the amount of export contracts insured by the export insurance services, increased from less than 1 percent throughout most of the 1970s to 2.7 percent in 1991. With the establishment of the KEIC, the amount of underwritten business in total exports has increased to over 20 percent since 2005, reaching 21.4 percent in 2006, as shown in Table 1.

\section{Table 1.}

The Tendencies of Export Insurance Fund, Values of Underwriting, and Coverage Ratio, 1969-2007

(unit: billion won, \%)

\begin{tabular}{c|c|c|c}
\hline years & $\begin{array}{c}\text { Export Insurance } \\
\text { Fund }\end{array}$ & $\begin{array}{c}\text { Values of } \\
\text { Underwriting }\end{array}$ & $\begin{array}{c}\text { Coverage } \\
\text { Ratio }\end{array}$ \\
\hline \hline 1969 & 0.3 & 1 & 0.6 \\
\hline 1974 & 1 & 6 & 0.3 \\
\hline 1979 & 10 & 259 & 2.5 \\
\hline 1984 & 20 & 1253 & 4.2 \\
\hline 1989 & 27 & 371 & 0.8 \\
\hline 1991 & 54 & 1508 & 2.7 \\
\hline 1996 & 327 & 12409 & 13.2 \\
\hline 2001 & 1208 & 37316 & 17.6 \\
\hline 2006 & 1831 & 82700 & 21.4 \\
\hline 2007 & 1982 & n. a. & n. a. \\
\hline
\end{tabular}

n.a.: not available

Source: KEIC, Ten Year History of KEIC, KEIC: Seoul, 2003 (in Korean); http://www.keic.or.kr, retrieved July 5, 2008 
The values of premium revenue increased from less than .1 billion won until 1974 to 5.9 billion won in 1991 and then increased substantially with the establishment of the KEIC, reaching 223 billion won in 2007. Claims payments began to be recorded in 1973 and continued to increase to 43 billion won in 1991, 536 billion won in 2006, and 460 billion won in 2007. The loss ratio, which is usually defined as the amount of a claims payment divided by that of premium revenue, has remained above 200 percent since 1990 , as is shown in Table 2 .

Table 2.

The Tendencies of Premium Revenue, Claims Payment, and Loss Ratio, 1969-2007

(unit: 100 million won)

\begin{tabular}{c|c|c|c|c}
\hline years & $\begin{array}{c}\text { export insurance } \\
\text { claims }\end{array}$ & $\begin{array}{c}\text { export insurance } \\
\text { premia }\end{array}$ & recoveries & $\begin{array}{c}\text { administrative } \\
\text { costs }\end{array}$ \\
\hline \hline 1969 & 0 & 0.1 & 0 & 0.2 \\
\hline 1974 & 0.2 & 0.7 & 0.0 & 0.5 \\
\hline 1979 & 4.1 & 7.5 & 0.4 & 4.7 \\
\hline 1984 & 11.5 & 78.5 & 0.7 & 20.0 \\
\hline 1989 & 13.8 & 12.4 & 4.5 & 34.4 \\
\hline 1991 & 433.9 & 58.5 & 3.8 & 52.3 \\
\hline 1996 & 721.3 & 515.1 & 113.2 & 263.6 \\
\hline 2001 & 3604.9 & 846.2 & 205.1 & 292.9 \\
\hline 2006 & 5359.9 & 1080.7 & 1157.0 & 576.5 \\
\hline 2007 & 4596.2 & 2230.0 & 1718.0 & 598.2 \\
\hline
\end{tabular}

Source: KEIC, Ten Year History of KEIC, KEIC: Seoul, 2003 (in Korean); KEIC, Twenty-Five Year History of KEIC, KEIC: Seoul, 2003 (in Korean)

Recoveries started from 1974, but began to increase substantially 1993, right after the establishment of the KEIC in 1992, reaching 172 billion won in 2007. Although most economic analyses ignore the effect of transaction costs on economic performance, ignoring their existence can lead to misleading results in empirical work. Therefore, the current analysis takes that into consideration. The amount of the administrative cost has shared as much as one-third or even over half of premium revenues throughout most of the years. For instance, during the period of 1992-2007, administrative costs totaled .51 trillion won, sharing about 62 percent of premium revenue (KEIC (1994; 2003); KEIC (various years), which can be compared with the case of the British export credit agency, i.e. the 
Export Credit Guarantee Department (ECGD). For the same period, the administrative costs of the British ECGD shared 30 percent of its premium revenue (ECGD, various years). It means that ignorance of transaction costs, as has been commonplace in most economic analyses, may lead to incorrect conclusions in empirical work.

When the export insurance incentive ratio is calculated as (claims payment + administrative cost) divided by (premium income + recoveries), it amounted to 186 percent during 2005-2007. The difference between expenditure and income has been compensated by contribution of the government, i.e. interest income from the Export Insurance Fund. Annex I.(k) of the UR Subsidies Code tells us that the premium rates, actually consistent with the Minimum Benchmark Premium (MBP) rates stipulated in the Knaepen Package of the OECD Arrangement, would not be regarded as export subsidies prohibited in the current WTO system (Mah and Song (2001). Since the current premium rates charged by the KEIC do not exceed the MBP rates, they are not prohibited by the current WTO regulations, while the government actually subsidizes the export insurance system of Korea.

\section{The Model and Data}

International economists have devoted considerable attention to estimating export demand and/or export supply functions. Assuming an export demand curve that is infinitely elastic with respect to price, the amount of export supply would be the same as the equilibrium export level. There have been many works estimating the effect of export relative prices defined as export price index over domestic price index on export supply, export subsidy has sometimes been studied as another determinant of export supply. Jung and Lee (1986) showed that export relative price and export subsidies had statistically insignificant effects on the export supply in Korea. Arslan and Wijnbergen (1993) assumed export values over national income to be determined by the relative price of exports and showed that export subsidies had a significant, positive effect on exports in Turkey. However, their analysis suggested that export subsidies were mostly shifted into higher producer profits rather than into lower foreign consumer prices, resulting in only moderate contributions of the export subsidies to the export boom.

Faini (1994) regressed export supplies on wages, real interest rates, domestic prices, export prices, price of investment goods and time trend capturing technical progress in Turkey and Morocco. His empirical evidence showed that capacity and export subsidy had statistically significant effects on export supply. Barlow and Senses (1995) assumed export supply to be determined by real domestic prices, real wages, tariff rates, foreign capital inflow and accumulated real investment. They showed that export subsidy had a positive and significant effect on Turkey's exports.

Overall, the above-mentioned papers argued that export subsidy promoted export supply. However, there are some problems in such empirical studies with respect to the 
effect of export subsidies on export supply. First, since provisions of export subsidies are prohibited in the WTO system, conducting studies on them would not be meaningful nowadays. Therefore, it would be worthwhile for international trade economists to deal with export incentives, such as export insurance, that are allowed in the current global trading system. Second, they have ignored transaction costs necessary for administering the concerned export promotion system. For instance, the amount of transaction costs share between one third and half of premium revenue of the export insurance system of Korea. Ignoring the transaction costs might have led to incorrect conclusions in the previous works. Moser, et. al. (2008) used a gravity model of exports with respect to the case of Germany's export credit system and showed that export credits have a positive effect on exports in Germany. However, they did not consider the role of transaction costs. Third, since the previous literature using the time series data did not consider the stationarity issue, the results may be those of spurious regression. That is, the empirical findings of those works cannot be reliable.

The following equation shows the effect of export incentives on export supply explained thus far:

$$
\log X Y(t)=a+b \log R P(t)+c \log E I(t)+e(t)
$$

where $\mathrm{XY}=$ export values divided by GDP; RP = export relative price, i.e. export price index divided by domestic price index, both expressed in terms of Korean won; $\mathrm{e}=$ the conventionally assumed error term; $\mathrm{EI}=1+$ export insurance incentive ratio which is defined in the current paper as (export insurance claims + administrative cost - export insurance premium - recovery)/export values. The definition of the export insurance incentive has been controversial. For instance, NEXI which is in charge of export insurance services in Japan defines it as the claims paid/premium revenue and calls it the loss ratio (NEXI (2008); meanwhile, according to Bagci, et al (2003), calculation of that includes the administrative costs. The current paper acknowledges the effect of the existence of transaction costs on export insurance incentives.

The estimated coefficient $b$ can be interpreted as the export relative price elasticity. Its sign is expected to be positive, since higher export prices compared with domestic prices would increase export supply. Since the provision of export subsidies increases exporters' profits, it is expected to increase export supply, resulting in $c>0$. Data for export values, GDP, export price index, and producer price index are taken from the Bank of Korea, http:://www.bok.or.kr, retrieved July 5, 2008. Data relating to export insurances are taken from KEIC $(1994,2003)$ and KEIC website, http://www.keic.or.kr, retrieved July $5,2008$.

Since regression analyses using non-stationary variables may lead to spurious regression, it is necessary to check the stationarity of the concerned variables. The annually 
observed data set in the current study covers the period 1971-2007. ${ }^{1}$ Unit root tests are performed with respect to the variables under consideration to test the stationarity. If the concerned variables are non-stationary, but integrated of the same order, it is necessary to check whether there exist long run equilibrium relationship(s) among the concerned variables. If there exist(s) at least one cointegrating vector, we can conclude that there are long run equilibrium relationship(s) among those variables even if they are non-stationary. If the cointegration test reveals that there does not exist such a relationship, then it would be necessary to use the first differenced data and rely on the regression analysis.

This paper starts from examining the stationarity property of the variables appearing in equation (1). If the variables under consideration are non-stationary, but integrated of the same order, it is necessary to use cointegration tests to examine the existence of the long run equilibrium relationships among the concerned variables. Banerjee, et. al.'s (1998) error correction mechanism (ECM) test would be appropriate for the cointegration test with a small sample size, where the critical values are available for a minimum sample size of only 25. It depends on the statistical significance of the ordinary least squares (OLS) coefficient of the lagged dependent variable in an autoregressive distributed lag model augmented with leads of the regressors. Specifically, the estimated $t$ statistics of the coefficient of the lagged dependent variable, tb, is derived from the following equation:

$$
A(L) d X Y(t)=B(L) d Z(t)+b X Y(t-1)+C Z(t-1)+S i=1 s f i d Z(t+i)+w(t)
$$

where $\mathrm{Z}$ and $\mathrm{w}$ show the vector of regressors consisting of RP and EI appearing in equation (1) and the conventionally assumed error term, respectively. $L$ and d denote the lag operator and the differenced form of the concerned variable, respectively. According to Banerjee, et. al. (1998), even $\mathrm{s}=1$ or 2 in equation (2) shows good properties. In Banerjee, et. al.'s ECM tests, the cointegration test results must rely upon the $\mathrm{t}$ statistics of $\mathrm{b}$ in the OLS estimation of equation (2). Under the null hypothesis of non-cointegration, $b$ would be equal to 0 , while under the alternative hypothesis of cointegration, $-2<\mathrm{b}<0$. Banerjee, et. al. (1998) show that their statistics have power in finite samples better than the other more often used cointegration tests.

\section{Empirical Evidence}

The augmented Dickey-Fuller (ADF) unit root test results show that the null hypothesis of non-stationarity of the concerned variables is not rejected at any reasonable level of significance, while the first differenced forms of those are revealed to be stationary

1 Export insurance service was introduced in 1969. Assuming the year of 1970 as that necessary for establishing the basic schemes relating to export insurance, the current study starts from the year 1971 . 
at a 5 or 1 percent level of significance, as is shown in Table 3 . Since the results may differ depending on the number of lags in the ADF test, an optimal number of lags is chosen by Schwarz criterion. Throughout the empirical analysis in the current paper it is assumed that all variables appearing in equation (1) are integrated of order one.

Table 3.

Augmented Dickey-Fuller Test Results on $\log \mathrm{XY}, \log \mathrm{RP}$, and $\log \mathrm{EI}$

\begin{tabular}{c|c|c}
\hline variables & level form & first differenced form \\
\hline \hline $\log \mathrm{XY}$ & -1.187 & $-5.834^{* *}$ \\
\hline $\log \mathrm{RP}$ & 0.436 & $-3.162^{*}$ \\
\hline $\log \mathrm{EI}$ & -2.504 & $-5.538^{* *}$ \\
\hline
\end{tabular}

Note: The variables used in Table 3 are defined in the following manner: XY = export values / GDP; RP = export price index / domestic price index; and $\mathrm{EI}=1.0+$ (export insurance claims + administrative cost - export insurance premium - recovery)/export value.

* statistically significant at 5 percent level of significance

** statistically significant at 1 percent level of significance

Table 4 shows the results of Banerjee, et. al.'s small sample cointegration test with respect to the variables appearing in equation (1). In addition to the results of running regressions on equation (1), Table 4 also shows those in case of adding the dummy variable, DUMMY, in the right hand side of the equation. DUMMY, which is equal to 1 if $t$ $>1991$ and $=0$ until $t=1991$, is included to reflect the effect of establishment of the export insurance institution, KEIC, in 1992. Regardless of the number of lags of $s$ in equation (2), Table 4 shows that the null hypothesis of non-cointegration is not rejected at a 5 percent level of significance. That is, there is no evidence of cointegration among the variables appearing in equation (1), according to Banerjee, et. al. 's (1998) ECM cointegration test. The results do not change when the dummy variable is included in the right hand side of the equation used in the small sample cointegration test, i.e. equation (2).

Table 4.

Banerjee, et. al.'s Small Sample Cointegration Test Statistics

\begin{tabular}{c|c|c}
\hline lag number of s in equation (2) & no DUMMY case & with DUMMY case \\
\hline \hline 1 & 0.210 & -0.699 \\
\hline 2 & 0.585 & -0.058 \\
\hline
\end{tabular}

Note: The dummy variable is defined as the following: DUMMY $=0$ until $\mathrm{t}=1991$ and $=1$ if $\mathrm{t}>1991$. 
Since Banerjee, et. al. 's cointegration tests reveal that a cointegration relationship does not exist, it is necessary to try the regression analysis using the first differenced forms of the variables which are revealed to be stationary. Table 5 shows the OLS estimation results when the first differenced forms of all variables appearing in equation (1) are used. The coefficient of export relative price is revealed to be significant at even 1 percent level of significance. It is estimated to be about 0.8 . Since the estimated coefficient can be regarded as the elasticity of export supply with respect to export relative price, we can say that a rise in export price compared with domestic price by one percent would lead to rise of export value over GDP by about 0.8 percent in Korea.

Provision of export insurance by the Korean government is revealed not to be significant at any reasonable level of significance in the current study. Although the current study considers transaction cost in analyzing the effect of export insurance on export supply unlike Mah (2006), it does not change the results qualitatively. Next, a dummy variable expressing the effect of establishment of the institution fully devoted to export insurance in 1992 is included in the right hand side of the export supply equation. The result, appearing in Table 5, shows that the estimated dummy variable is not statistically significant at any reasonable level of significance. Inclusion of the dummy variable is revealed not to contribute to improvement in the overall explanatory power. The estimated results of the coefficients of $\log$ RP and log EI do not change qualitatively, either.

Table 5.

OLS Estimation Results Using the First-differenced Data

\begin{tabular}{c|c|c|c|c|c|c}
\hline constant & $\log$ RP & $\log$ EI & DUMMY & adj. R2 & D.W. & F statistics \\
\hline \hline $0.046^{*}$ & $0.808^{* *}$ & 15.640 & & 0.189 & 0.956 & $5.074^{*}$ \\
\hline$(2.407)$ & $(3.145)$ & $(0.427)$ & & & & \\
\hline 0.035 & $0.832^{* *}$ & 17.167 & 0.026 & 0.176 & 0.946 & $3.495^{*}$ \\
\hline$(1.386)$ & $(3.185)$ & $(0.464)$ & $(0.702)$ & & & \\
\hline
\end{tabular}

Note: Values within the parentheses below the estimated coefficients denote the estimated t statistics.

*statistically significant at 5 percent level of significance

**statistically significant at 1 percent level of significance

\section{Conclusion}

The UR Subsidies Code stipulates that a Member of the WTO is neither allowed to grant nor maintain export subsidies that are provided contingent upon export performance. This paper focuses on the export insurance that can be considered as the most important export incentive that the governments of developed or upper middle income developing countries such as Korea can use in the current WTO system. 
Korea's share of exports insured by the export insurance system in the last a few decades has been one of the highest in the world, although the current operation of the Korean export insurance system is not prohibited under Annex I.(j) of the UR Subsidies Code. This paper examines whether export insurance incentives provided by the Korean government have significantly promoted export supplies of Korea, considering export relative prices and export insurance incentives as the possible determinants of export supply. Unlike the previous studies revealing the effectiveness of export subsidy in export supply, the current study examines the non-stationarity nature of the concerned variables. In addition, the current paper takes into consideration the existence of transaction costs in administering the export insurance system of Korea, which is different from the previous studies that ignored the transaction cost in the empirical analysis. The unit root tests show that all concerned variables are integrated of order one. Banerjee, et. al.'s (1998) small sample cointegration test results show that there is no long run equilibrium relationship among the concerned variables, i.e. export values, export relative price and export incentive expressed in terms of provision of export insurance.

The empirical evidence in the current study using the first differenced data show that the coefficient of export relative price is statistically significant at any reasonable level of significance and its elasticity is estimated to be slightly less than one. The export incentive in terms of provision of export insurances by the government is revealed to be not significant in promoting export supply of Korea at any reasonable level of significance, which is different from the conclusions of most previous literature that assumed the amount of transaction cost to be equal to zero and ignored the non-stationarity nature of the concerned variables. That is, the export insurance incentives provided by the Korean government did not contribute to promoting export supply.

The little contribution of the export insurance system in export promotion might be due to the existence of a substantial amount of administration costs leading to inefficient functioning of the export incentive system or the exporters' concerns that the increase of exports with export insurance incentives exceeding a certain threshold level may be subject to the administered protection measures of importing countries such as the imposition of countervailing duties. For the improvement of the current export insurance system, it may be necessary to strengthen the KEIC's support of small and medium enterprises' export activities. In addition, a reduction in the amount of transaction costs would be advised, which may include streamlining the insurance types currently offered, but seldom utilized by exporters. ${ }^{2}$

2 The author wishes to express his sincere thanks to the seminar participants at the University of Connecticut. This work was supported by the Korea Research Foundation Grant funded by the Korean Government (KRF-2006-321-B00342). 


\section{References}

Abraham, Filip, Inge Couwenberg and Gerda Dewit, Towards an EC Policy on Export Financing Subsidies: Lessons from the 1980s and Prospects for Future Reform, The World Economy, Vol. 15, No. 3, May 1992, 389 - 405.

Arslan, Ismail and Sweder van Wijnbergen, Export Incentives, Exchange Rate Policy and Export Growth in Turkey, Review of Economics and Statistics, Vol. LXXV, No. 1, February 1993, 128 - 133.

Bagci, Pinar, et al., Estimating the Economic Costs and Benefits of ECGD, London: NERA Economic Consulting, 2003.

Banerjee, Anidya, Juan J. Dolado and Richardo Mestre, Error-Correction Mechanism Tests for Cointegration in a Single-Equation Framework, Journal of Time Series Analysis, Vol. 19, No. 3, May 1998: 267-283.

Barlow, Robin and Fikret Senses, The Turkish export boom: Just reward or just lucky?, Journal of Development Economics, Vol. 48, No. 1, October 1995, 111 - 133.

Chao, Chi-Chur, W. L. Chou., and Eden S. H. Yu, Export Duty Drawbacks and Export Performance: Theory and China's Experience, Journal of Comparative Economics, Vol. 29, 2001: 314-326.

Export Credits Guarantee Department (ECGD), Anmual Review, London: Export Credits Guarantee Department, various years (available at http://www.ecgd.gov.uk, retrieved June 15, 2008).

Faini, Riccardo, Export supply, capacity and relative prices, Journal of Development Economics, Vol. 45, No. 1, October 1994, 81 - 100.

Jung, Woo S., and Gyu Lee, The Effectiveness of Export Promotion Policies: The Case of Korea, Weltwirtschaftliches Archiv, Vol. 122, No. 2, 1986, 340 - 357.

Korea Export Insurance Corporation (KEIC), Twenty-Five Years History of KEIC, KEIC: Seoul, 1994. KEIC, Ten Years History of KEIC, KEIC: Seoul, 2003.

KEIC, http://www.keic.or.kr, retrieved July 5, 2008.

Mah, Jai S., The Effect of Export Insurance on Export Promotion: the Case of Japan, Journal of Asian Economics, Vol. 17, No. 4, August 2006: 646 - 652.

Mah, Jai S., Duty Drawback and Export Promotion in China, Journal of Developing Areas, Vol. 40, No. 2, Spring 2007: 141 - 156.

Mah, Jai S., and Chris Milner, The Japanese Export Insurance Arrangements: Promotion or subsidisation?, The World Economy, Vol. 28, No. 2, February 2005, 231 - 242.

Mah, Jai S., and Yunah Song, The Korean Export Insurance System: Its Implications in the Global Trading System, Journal of World Trade, Vol. 35, No. 4, August 2001, 603 - 614.

Moser, Christopher, Thorsten Nestmann and Michael Wedow, Political Risk and Export Promotion: Evidence from Germany, The World Economy, Vol. 31, No. 6, June 2008: 781 - 803.

Nippon Export Insurance (NEXI), http://www.nexi.go.jp, retrieved May 18, 2002. 